\title{
SOME ASPECTS OF THE ECOLOGY OF FISH LARVAE IN THE FLOODPLAIN OF THE HIGH PARANÁ RIVER, BRAZIL
}

\author{
Gilmar Baumgartner ${ }^{1}$ \\ Keshiyu Nakatani ${ }^{1}$ \\ Maristela Cavicchioli ${ }^{1}$ \\ Maria do Socorro Tenório Baumgartner ${ }^{1}$
}

\begin{abstract}
The spatial and temporal distribution and nychthemeral variation of fish larvae in six stations (Ivinhema, Patos, Paraná, Cortado, Baia and Guaraná) in the floodplain of the high Paraná river are provided. The paper also provides the relationship of this distribution to some environmental factors. From March 1992 to February 1993 ichthyoplanktonic samples were collected by conic cylindrical nets, with $0.5 \mathrm{~mm}$ of mesh size and fluxometer attached, in 10-minute hauls at the surface and bottom during nychthemeral cycles. At the same time water samples were taken to determine environmental factors. During the above period 5,672 larvae were collected: $57,6 \%$ from Cortado station and 13,2\% from Ivinhema and Paraná stations. The greatest densities were recorded between October and February, chiefly at night at the surface and by day at the bottom.
\end{abstract}

KEY WORDS. Fish larvae, ecology, distribution, floodplain, Paraná river

Floodplains are areas seasonally submitted to severe modifications in their physical, chemical and hydrological characteristics and in their animal and vegetal communities. These changes are incorporated to the life cycle of various species. In the flood periods when the water volume transported by the river is very great, the decomposition of vegetation, animal excrements, autochthonous and allochthonous organic material cause a considerable enrichment of the water due to the great quantity of organic and inorganic nutrients produced in the process. This factor greatly favours the proliferation of bacteria, phytoplankton and zooplankton, organisms that uphold a rich fauna of invertebrates and vertebrates in all the environments of the floodplain. The biomass is heavily exploited by fish in their initial phases of development causing their rapid growth, bypassing the stages most vulnerable to predation.

For a better understanding of the environmental mechanisms that influence the behaviour of fishes it is necessary to know the relationship between the occurrence and the distribution of eggs and larvae and the environmental conditions of spawning and growth areas. It is also necessary to register annual oscillations and to detect tendencies of a community, population or stock throughout a certain period of time. This will result in a bettering of knowledge on reproduction, ontogeny and taxonomy of these groups (MATSUURA 1977; SYNDER 1983)

1) Departamento de Biologia, Nupélia, Universidade Estadual de Maringá. Avenida Colombo 5790, 87020-900 Maringá, Paraná, Brasil. 
Thus, the present research work developed in different environments of the floodplain of the high Paraná river aims to analyse the spatiotemporal distribution and nychthemeral variation of fish larvae, to relate the distribution of larvae to some environmental factors, to evaluate the diversity, equitability and richness of species and to analyse the ichthyoplanktonic similarity of the environments.

\section{MATERIALS AND METHODS}

Sampling was undertaken at six stations (Ivinhema, Patos, Paraná, Cortado, Baía and Guaraná) lying in the floodplain of the high Paraná river ( $22^{\circ} 40^{\prime}$ to $22^{\circ} 50^{\prime} \mathrm{S}$ and $53^{\circ} 10^{\prime}$ to $53^{\circ} 40^{\prime} \mathrm{W}$ ) (Fig. 1).

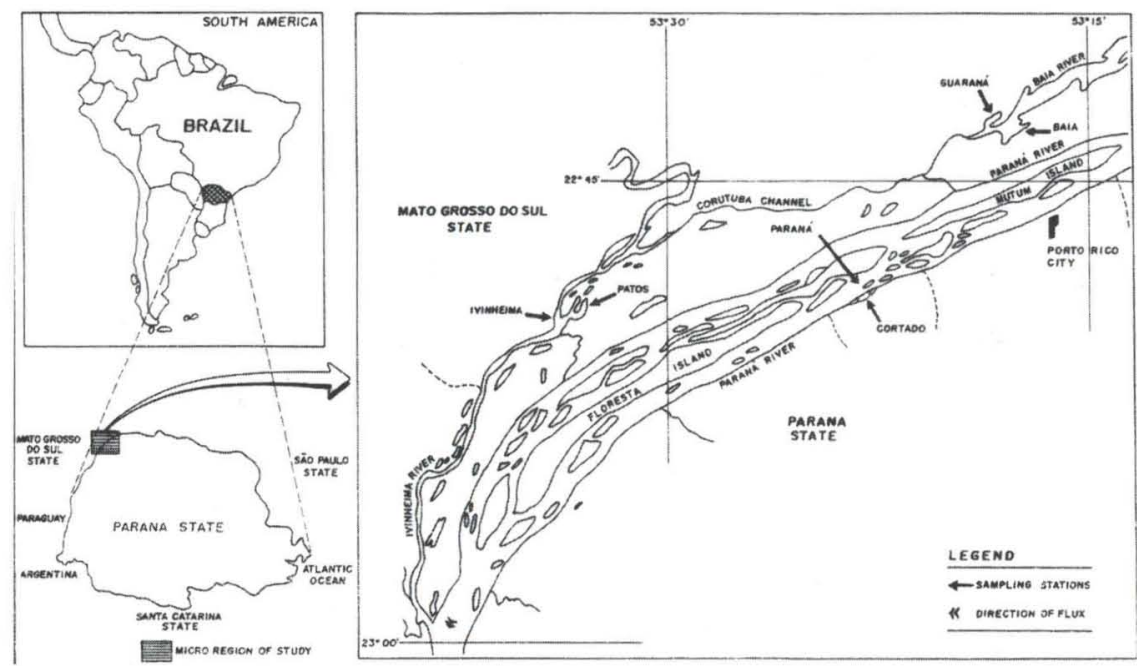

Fig. 1. Site of the sampling stations.

Surface and bottom samplings were collected monthly in nychthemeral cycles at four-hour intervals between March 1992 and February 1993. Surface samplings were undertaken by a conical cylindrical net of $0.5 \mathrm{~mm}$ mesh size. Bottom samplings were undertaken by a hauling dredger with the same type of net. Both instruments equipped with fluxometer at the mouth were drawn for 10 minutes.

Samples of the water for environmental data (temperature, dissolved oxygen, $\mathrm{pH}$ and electrical conductivity) were taken at the surface and bottom with a Van Dorn jar. Concentrations of dissolved oxygen were determined by Winkler's method modified by GolTERMANN et al. (1978). Data on fluviometric levels were given by the Departamento Nacional de Água e Energia Elétrica (DNAEE).

Estimates for abundance of larvae were calculated according to TANAKA (1973), modified. Relative Density (RD) was given through the formula $\mathrm{RD}=\mathrm{C} / \mathrm{B}$, where " $C$ " the total number of collected larvae and " $\mathrm{B}$ " the number of stations with larvae occurrence. 
The association between the abiotic variables and larvae densities was undertaken through the Principal Components Analysis (PCA) and its aim was to verify interdependence among the variables (MANLY 1995). Data matrix was composed by 6 variables (water temperature, $\mathrm{pH}$, electric conductivity, dissolved oxygen, fluviometric level and day duration) and 72 observations. Data were previously standardized since they were units of distinct measurements.

Scores of the Principal Components Analysis applied to the abiotic data were used as explanatory variables of the organism's densities which were previously given in logaritms with the addition of a constant (1).

\section{RESULTS}

A total of 5,672 fish larvae were collected in the floodplain of the high Paraná River between March 1992 and February 1993 (Tab. I).

Table I. Total number of larvae collected during the period.

\begin{tabular}{|c|c|c|}
\hline Station & Number of larvae & Percentage \\
\hline Cortado & 3,270 & 57.7 \\
\hline Paraná & 751 & 13.2 \\
\hline Ivinhema & 751 & 13.2 \\
\hline Patos & 388 & 6.8 \\
\hline Guaraná & 348 & 6.2 \\
\hline Baía & 164 & 2.9 \\
\hline Total & 5,672 & 100.0 \\
\hline
\end{tabular}

\section{Distribution and abundance of fish larvae}

At the Ivinhema station (Fig. 2A) the largest catches occurred at the surface. The period of occurrence was between August and March with largest catches from January to March at the surface and in January at the bottom. The greatest density of larvae caught during these month coincide with the highest temperatures (over $25.0^{\circ} \mathrm{C}$ ), dissolved oxygen with concentrations between 4.0 and $8.0 \mathrm{mgl}^{-1}$, greater electric conductivity (over $40.0 \mu \mathrm{Scm}^{-1}$ ), $\mathrm{pH}$ between 6.5 and 7.5 and high fluviometric level.

The period of capture of larvae in the Patos station (Fig. 2B) was from October to April. No recording of larvae occurred in December at the two levels; in October and April larvae occurred at the surface. The months of the largest catches at the surface were November and January; at the bottom the largest capture occurred in January. The greatest captures of larvae coincided with high temperatures, high electric conductivity, $\mathrm{pH}$ close to neutral, dissolved oxygen in concentrations between 4.0 and $8.0 \mathrm{mgl}^{-1}$, rising fluviometric level.

The greatest density of larvae at the Paraná station (Fig. 2C) occurred at the bottom. The period of capture occurred from October to April (with recordings in August too). The greatest densities of larvae occurred in November and from January to February at the surface, and from November to January at the bottom. 
The greatest densities of larvae coincided with high water temperatures (over $25.0^{\circ} \mathrm{C}$ ), dissolved oxygen with concentrations over $4.0 \mathrm{mgl}^{-1}$, electric conductivity over $40.0 \mu \mathrm{Scm}^{-1}$ and a slightly basic $\mathrm{pH}$.

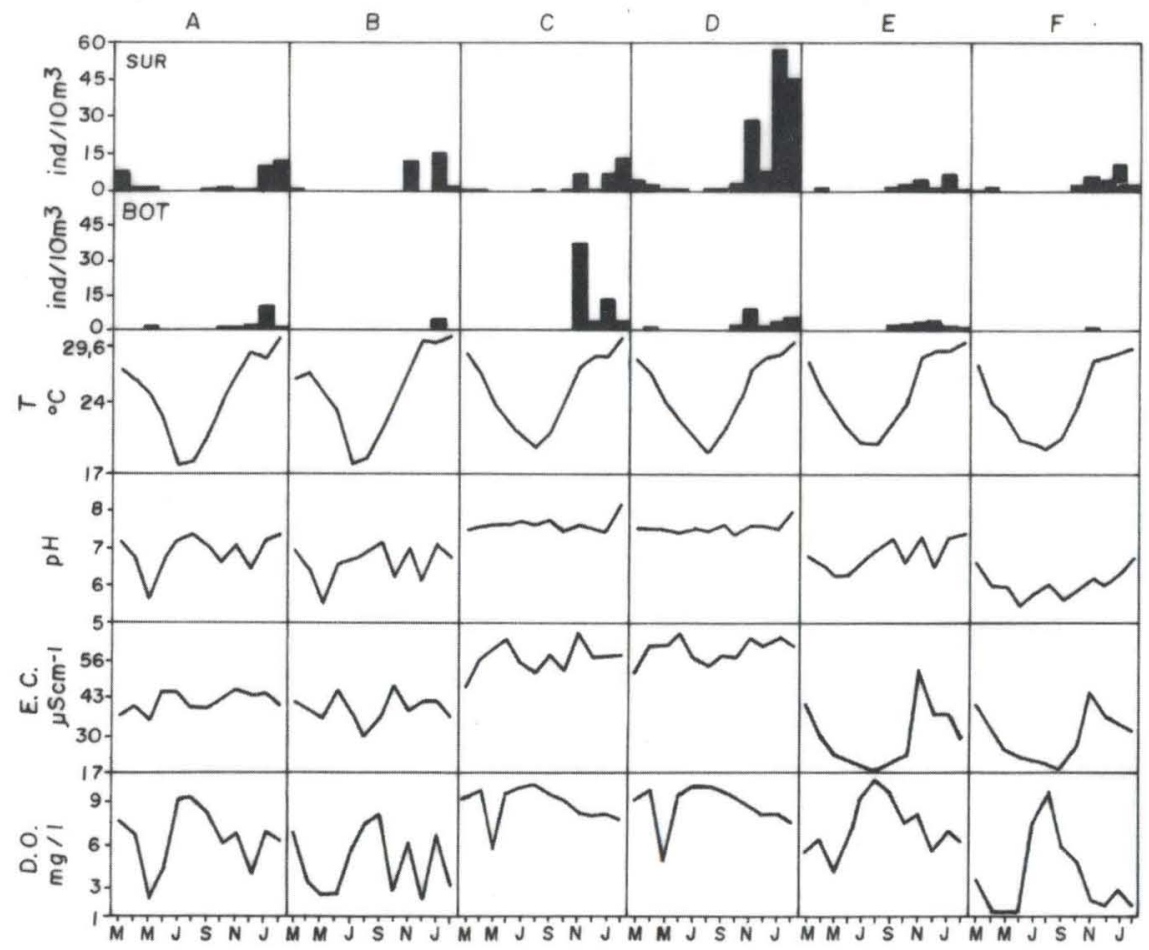

Fig. 2. Relative density of larvae at surface and bottom, temperature, dissolved oxygen, electric conductivity and $\mathrm{pH}$ at stations: (A) Ivinhema, (B) Patos, (C) Paraná, (D) Cortado, (E) Baía and (F) Guaraná.

In the Cortado station (Fig. 2D) individuals at the surface were predominant during the whole period. The greatest densities at the surface occurred in November, January and February; at the bottom in November. The greatest densities coincided with temperature over $25.0^{\circ} \mathrm{C}$, dissolved oxygen over $4.0 \mathrm{mgl}^{-1}$, electric conductivity over $40.0 \mu \mathrm{Scm}^{-1}$ and $\mathrm{pH}$ close to basic, rising fluviometric level.

In the Baía station (Fig. 2E) larvae were collected between September and February with a small occurrence in April. The greatest density at the surface happened in January; at the bottom it was verified in December. The period of greatest occurrence of larvae coincided with high temperatures (over $25.0^{\circ} \mathrm{C}$ ), dissolved oxygen in concentrations from 4.0 to $8.0 \mathrm{mgl}^{-1}$, electric conductivity between 30.0 and $40.0 \mu \mathrm{Scm}^{-1}$, $\mathrm{pH}$ close to neutral and rising fluviometric level.

In the Guaraná station (Fig. 2F) larvae were captured at the surface between October and April (with the exception of March), with greatest density in January. 
At the bottom larvae were recorded only in November. The greatest density of larvae coincided with temperatures over $25.0^{\circ} \mathrm{C}$, dissolved oxygen in concentration lower than $4.0 \mathrm{mgl}^{-1}$, electric conductivity between 30.0 and $40.0 \mu \mathrm{Scm}^{-1}, \mathrm{pH}$ lower than 6.5 and high fluviometric level.

\section{Nychthemeral variation}

In the Ivinhema station (Fig. 3A) the greatest densities of larvae at the surface occurred during the evening with a peak at $20: 00$ hours $\left(8.56 \mathrm{ind} / 10 \mathrm{~m}^{3}\right)$, with a decrease at the first hours of the morning. No register was made at 16:00 hours. At the bottom greatest densities were recorded during the day with a peak at 8:00 hours $\left(6.01 \mathrm{ind} / 10 \mathrm{~m}^{3}\right)$.

In the Patos station an analysis of the presence of larvae with regard to time (Fig. 3B) showed that at the surface larvae occurred only in the night period (between 20:00 hours and 4:00 hours), with a peak at 20:00 hours $\left(14.10 \mathrm{ind} / 10 \mathrm{~m}^{3}\right)$. At the bottom capture occurred at all hours, with a peak at 20:00 hours (18.28 ind $\left./ 10 \mathrm{~m}^{3}\right)$.

The largest capture of larvae in the Parana station (Fig. 3C) occurred in the night period at the surface, with a peak at 0:00 hour with 10.03 ind $/ 10 \mathrm{~m}^{3}$. At the bottom captures were more regular during the night and day periods, with peak at $0: 00$ hour with $45.11 \mathrm{ind} / 10 \mathrm{~m}^{3}$. At the surface the greatest capture occurred only at 4:00 hours. At other times capture at the bottom was predominant.

At the Cortado station an analysis of capture with regard to time (Fig. 3D) showed that the greatest density of individuals occurred during the night period with peak at 0:00 hour and 4:00 hours ( 25.51 and $24.76 \mathrm{ind} / 10 \mathrm{~m}^{3}$ respectively) at the surface and 20:00 hours $\left(12.00 \mathrm{ind} / 10 \mathrm{~m}^{3}\right)$ at the bottom. At the surface there was an increase in density during the night, with a decrease during the day; as from 20:00 hours a decrease occurred at the bottom till 8:00 hours. A rise occurred at 12:00 hours falling to negligible levels at 16:00 hours.

At the Baia station (Fig. 3E) the greatest capture at the surface occurred during the night with peak at 0:00 hour $\left(7.38 \mathrm{ind} / 10 \mathrm{~m}^{3}\right)$. At the bottom the relative density between the day and night periods varied slightly. However, the greatest densities occurred at 0:00 hour $\left(1.67 \mathrm{ind} / 10 \mathrm{~m}^{3}\right)$ and at $12: 00$ hours $\left(1.42 \mathrm{ind} / 10 \mathrm{~m}^{3}\right)$.

At the surface of the Guaraná station (Fig. 3F) the greatest density occurred during the night period with peak at 20:00 hours $\left(14.42 \mathrm{ind} / 10 \mathrm{~m}^{3}\right)$, with a decrease during the day. There was no occurrence at 16:00 hours. There was one occurrence at the bottom at 8:00 hours.

\section{Identification of larvae in the principal fish groups}

Thirteen taxonomic groups (Fig. 4A, B) were identified among the larvae captured at the Ivinhema station, with eight at the surface and 11 at the bottom. At the surface larvae of Characiforms $\left(4.73 \mathrm{ind} / 10 \mathrm{~m}^{3}\right)$ were predominant, followed by Siluriforms $\left(2.16 \mathrm{ind} / 10 \mathrm{~m}^{3}\right)$ and by Auchenipterus nuchalis (Spix, 1829) (1.10 ind $\left./ 10 \mathrm{~m}^{3}\right)$. At the bottom Pimelodus sp. was the greatest capture $\left(2.22 \mathrm{ind} / 10 \mathrm{~m}^{3}\right)$ followed by Pimelodidae $\left(1.78 \mathrm{ind} / 10 \mathrm{~m}^{3}\right)$ and Characiforms $\left(1.73 \mathrm{ind} / 10 \mathrm{~m}^{3}\right)$. 

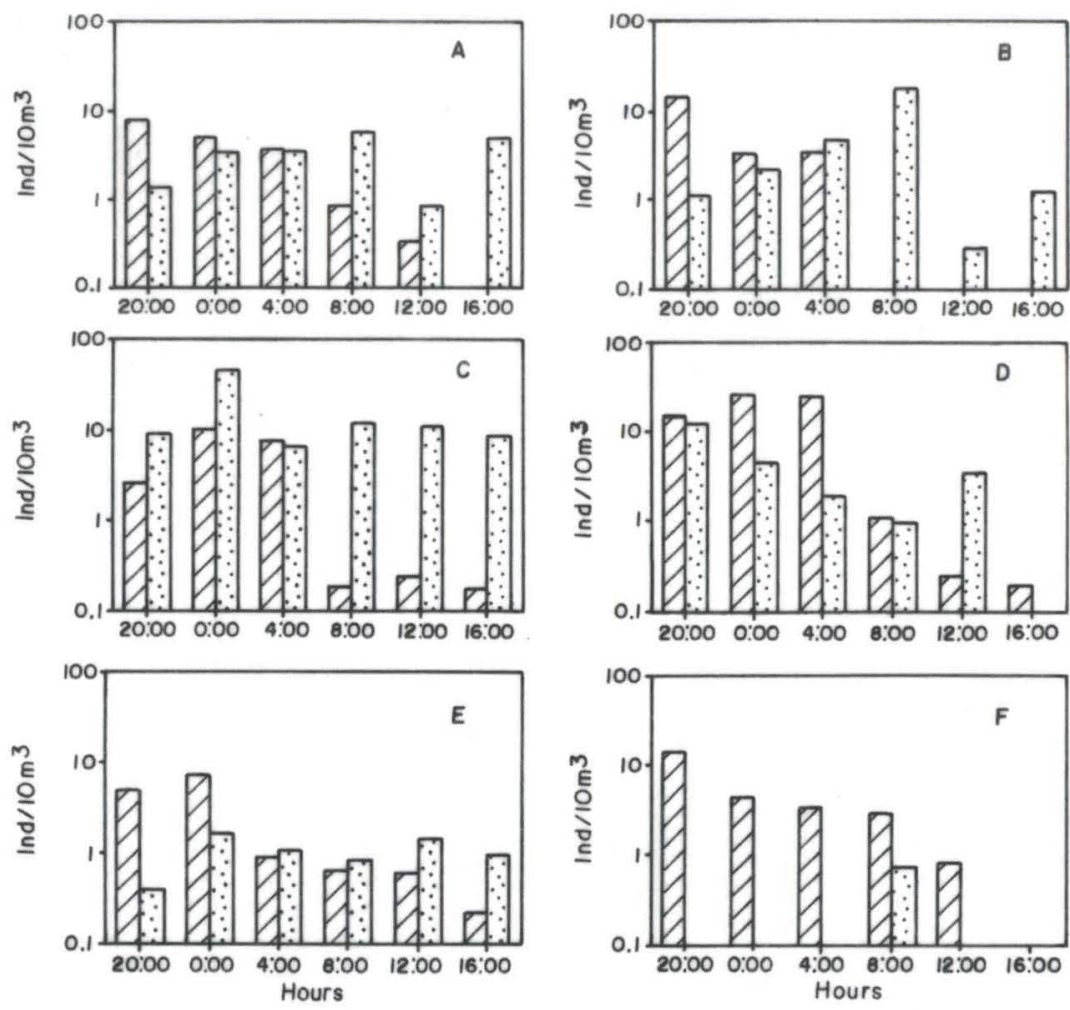

D SURFACE QBOTTOM

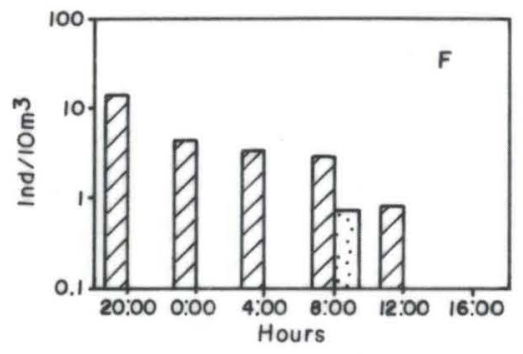

口 SURFACE QBOTTOM

Fig. 3. Relative density of larvae at different times at the surface and bottom for stations: (A) Ivinhema, (B) Patos, (C) Paraná, (D) Cortado, (E) Baía and (F) Guaraná.

At the Patos station 8 taxonomic groups were identified (Fig. 4C, D) with the greatest capture occurring at the bottom (8). At the surface the larvae of Characiforms were the most captured $\left(5.82 \mathrm{ind} / 10 \mathrm{~m}^{3}\right)$, followed by Siluriforms $\left(2.08 \mathrm{ind} / 10 \mathrm{~m}^{3}\right)$ and Pimelodidae $\left(0.88 \mathrm{ind} / 10 \mathrm{~m}^{3}\right)$. At the bottom the greatest capture was of larvae of Bryconamericus sp. $\left(5.97 \mathrm{ind} / 10 \mathrm{~m}^{3}\right)$, followed by Pimelodidae and Loricariichthyes platymetopon (Isbrücker \& Nijssem, 1979) (1.32 and $1.17 \mathrm{ind} / 10 \mathrm{~m}^{3}$ respectively).

Among the larvae captured at the Paraná station, 10 taxonomic groups were identified (Fig. 4E, F), with seven at the surface and eight at the bottom. At the surface the greatest capture consisted of Characiforms $\left(6.02 \mathrm{ind} / 10 \mathrm{~m}^{3}\right)$, followed by Hypophthalmus edentatus (Spix, 1829) and Siluriforms $\left(0.67\right.$ and $0.65 \mathrm{ind} / 10 \mathrm{~m}^{3}$ respectively). At the bottom, L. platymetopon was captured in greater density ( 14.60 ind $\left./ 10 \mathrm{~m}^{3}\right)$, followed by Characiforms and $H$. edentatus $\left(6.72\right.$ and $3.78 \mathrm{ind} / 10 \mathrm{~m}^{3}$, respectively). There was a high density of unidentified larvae $\left(26.10 \mathrm{ind} / 10 \mathrm{~m}^{3}\right)$ with yolk sac. Their smallness made identification impossible. 


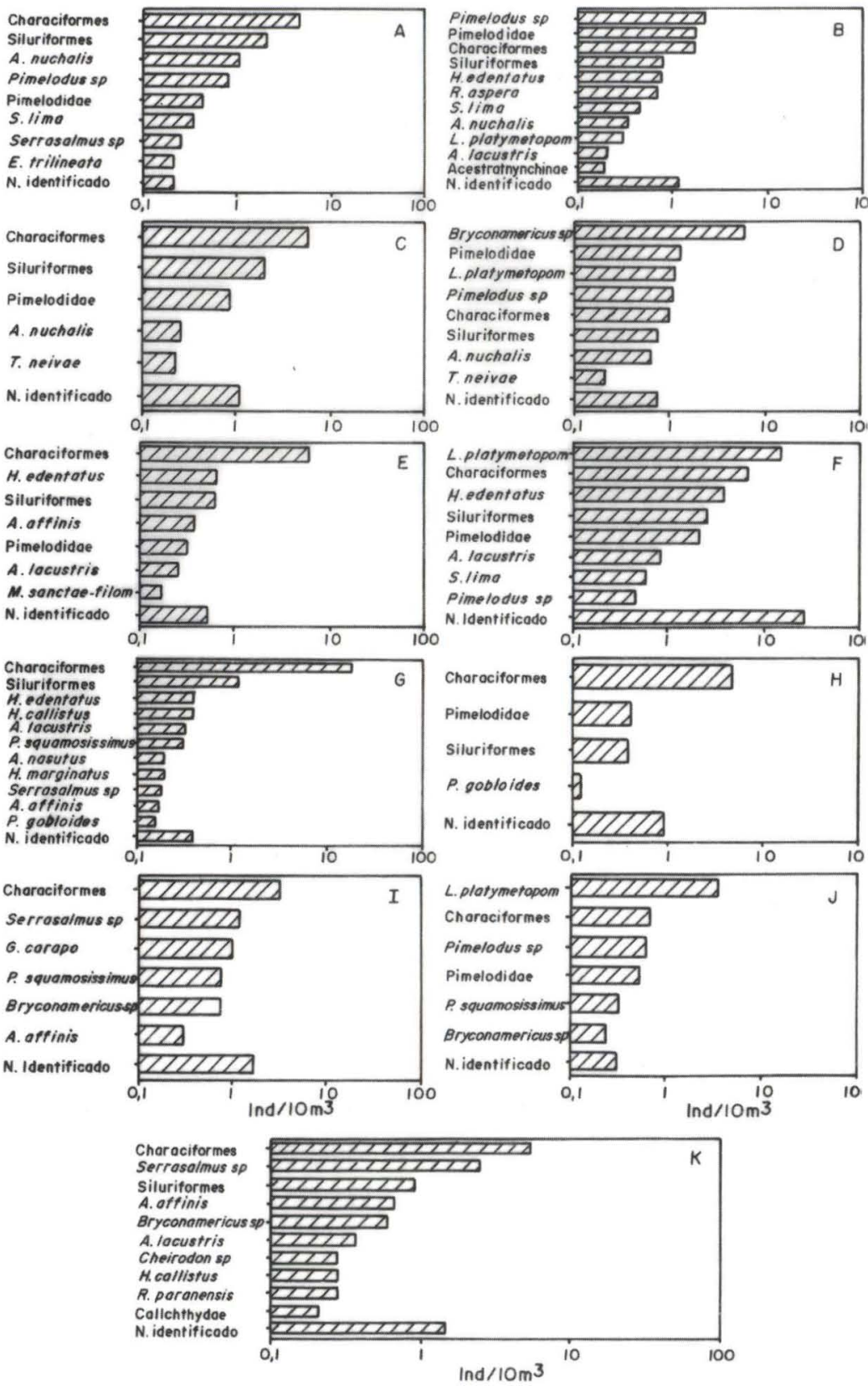

Fig. 4. Relative Density of principal taxonomical groups identified at stations: (A) Ivinhema surface, (B) Ivinhema bottom, (C) Patos surface, (D) Patos bottom, (E) Paraná surface, (F) Paraná bottom, (G) Cortado surface, (H) Cortado bottom, (I) Baia surface, (J) Baía bottom and (K) Guaraná surface. 
In the Cortado station 12 taxonomic groups were identified (Fig. 4G, H). At the surface Characiforms were predominant $\left(18.41\right.$ ind $\left./ 10 \mathrm{~m}^{3}\right)$, followed by Siluriforms $\left(1.17 \mathrm{ind} / 10 \mathrm{~m}^{3}\right)$. At the bottom the greatest capture consisted of Characiforms $\left(4.71 \mathrm{ind} / 10 \mathrm{~m}^{3}\right)$, followed by Pimelodidae and Siluriforms $\left(0.42\right.$ and $0.39 \mathrm{ind} / 10 \mathrm{~m}^{3}$ respecitively).

Nine taxonomic groups were identified in the Baía station (Fig. 4I, J). At the surface Characiforms formed the greatest density $\left(3.28 \mathrm{ind} / 10 \mathrm{~m}^{3}\right)$, followed by Serrasalmus sp. and Gymnotus carapo (Linnaeus, 1758) (1.22 and $0.97 \mathrm{ind} / 10 \mathrm{~m}^{3}$ ). At the bottom L. platymetopon were the most captured $\left(3.57 \mathrm{ind} / 10 \mathrm{~m}^{3}\right)$, followed by Characiforms $\left(0.70 \mathrm{ind} / 10 \mathrm{~m}^{3}\right)$.

It may be observed from figure $4 \mathrm{~K}$ that at the surface of the Guaraná station 10 taxonomic groups were identified. Characiforms were the most captured (5.49 ind $\left./ 10 \mathrm{~m}^{3}\right)$, followed by Serrasalmus sp. and Siluriforms $\left(2.52\right.$ and $0.91 \mathrm{ind} / 10 \mathrm{~m}^{3}$ respectively). Larvae captured at the bottom were too small. They had a yolk sac but their identification was not possible.

Interrelationship between occurrences of larvae and environmental factors

The figure 5 shows that the period of greatest density of larvae (over 1.01 ind $/ 10 \mathrm{~m}^{3}$ ) was longer (four to seven months) in the lotic compartments of the system (Ivinhema, Paraná and Cortado stations) and smaller (three months) in almost lentic (Baía station) and lentic ones (Patos and Guaraná stations).

\begin{tabular}{|l|l|l|l|l|l|l|l|l|l|l|l|}
\hline$M$ & $A$ & $M$ & $J$ & $J$ & $A$ & $S$ & $O$ & $N$ & 0 & $J$ & $F$ \\
\hline
\end{tabular}

Number of Months

PAR
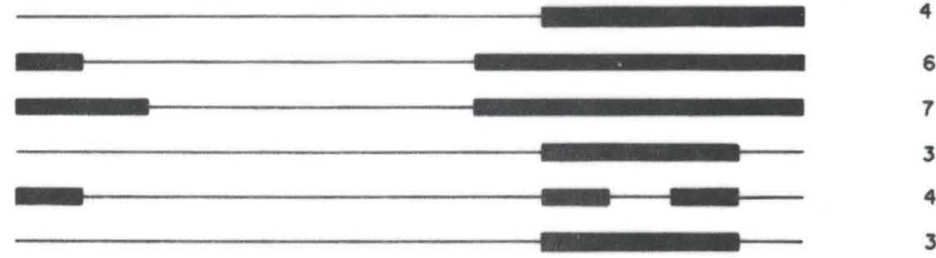

IVI

COR

BAI

PAT

GUA

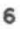

7

3

4

3

System

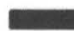

6

Fig. 5. Period in which larvae were captured in the six sampling stations and in the system as a whole: (PAR) Paraná, (IVI) Ivinhema, (COR) Cortado, (BAI) Baía, (PAT) Patos, (GUA) Guaraná and (System) system as a whole.

Among the six possible principal components only the first two were used for interpretation since they were only ones with autovalues higher than 1,0 (Kaiser-Guttman's criterious). Principal components I and II together explained $79,48 \%$ of the abiotic data's variability.

Water temperature, fluviometric level and day duration were correlated positively to PCI with structure coeficient higher than 0.5 . PCII was positively correlated to $\mathrm{pH}$, electric conductivity and dissolved oxygen (Tab. II). 
Table II. Pearson's correlation between scores of principal components and log values of larvae densities. (ns) not significance at the stated significance level $(p<0.05)$.

\begin{tabular}{|c|c|c|}
\hline Components & $\mathrm{PCl}$ & PCII \\
\hline Water temperature & 0.962 & -0.075 \\
\hline $\mathrm{pH}$ & 0.219 & 0.937 \\
\hline Electric conductivity & 0.388 & 0.743 \\
\hline Dissolved oxygen & -0.299 & 0.863 \\
\hline Fluviometric level & 0.869 & -0.246 \\
\hline Day duration & 0.746 & 0.067 \\
\hline Autovalues & 2.525 & 2.244 \\
\hline Percentage of explanation & 42.090 & 37.390 \\
\hline Correlation with log of larvae density & 0,717 & 0.195 \\
\hline Probability & 0,000 & ns \\
\hline
\end{tabular}

Density variability of larvae can be explained by the first linear combination (PCI) which maximizes abiotic data variance. The Pearson's correlation between principal component I and larvae density values in the log scale was high (Fig. 6).

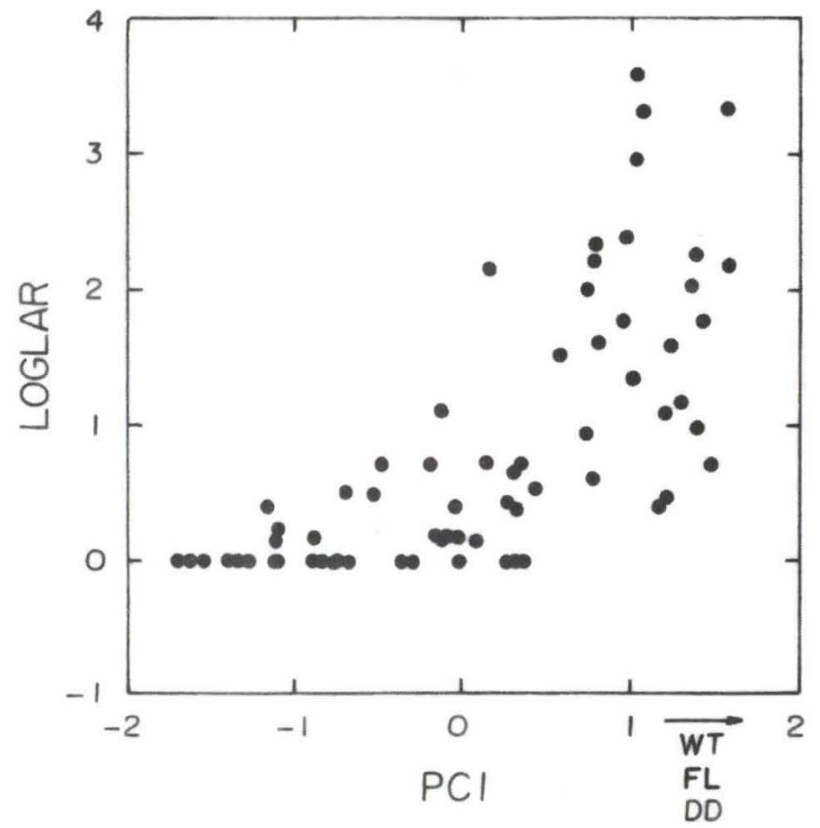

Fig. 6. Relationship between the log of larvae density and pricipal component 1: (WT) water temperature, (FL) fluviométric level and (DD) day duration.

\section{DISCUSSION}

The flooding regime and the variations of pluviometric indexes are the chief factors that seasonally regulate the principal ecological factors of the floodplains (JUNK 1980). According to ESTEVES (1988) floodings cause changes in the phyto- 
planktonic, zooplanktonic, benthic, ichthyic and aquatic macrophyte communities with regard to feeding, stimulus for migration, spawning and survival of eggs and larvae. All these processes may be influenced by changes in the physical and chemical conditions of water chiefly during the flooding period. While enhancing the importance of the flooding regime in the floodplain of the high Parana river, THOMAZ et al. (1992) verified that the widening of the floodplain of the high Parana river in the period 1986-1988 resulted in great changes in limnological characteristics such as transparency of the water column, dissolved oxygen, nutrients and chlorophylla.

In the present research work the three environments with the greatest capture of larvae (Cortado, Ivinhema and Paraná) have lotic waters. Thus, various species of fish spawn in these environments. Consequently water currents carry away their larvae. Similar behaviour was certified by GODOY (1954) for Prochilodus scrofa (Steindachner, 1882) and by MORAES-FILHO \& SCHUBART (1955) for the dourado (Salminus maxillosus Valenciennes, 1829) in the River Mogi-Guaçu. With regard to the lower river Tocantins CARVALHO \& MERONA (1986) established that Hypophthalmus marginatus (Vaillant, 1879) and Prochilodus nigricans (Agassiz, 1829) spawn during the flood and in speed river. Their larvae and eggs are carried away by the water current to feeding and growth sites.

The period of the greatest density of larvae (November to March) coincides with the period of greatest reproductive activity of the species of the region. The seasonal factor in larvae occurrence was also verified by NAKATANI et al. (1993) with larvae of the "curvina" in environments of the Paraná river basin. The environmental factors related to the greatest densities of larvae were high temperatures, high or rising fluviometric level and greater duration of the day. This fact was enhanced by the analysis of principal components. GoDOY (1975) adds that as a general rule spawning of migratory fish coincides with the highest water temperatures. NIKOLSKI (1963) says that the influence of temperature in the development of eggs and larvae consists in temperature variation which changes the velocity of chemical and biochemical reactions.

While enhancing the importance of the fluviometric level on fish communities, Cordiviola DE YUAN (1992) observes that oscillation of water level is the most influencial factor on fish communities in lentic environments in the floodplain of the middle Paraná river in Argentina. The region comprised in this study is the last non-dammed stretch of the Paraná river in Brazilian territory. The construction of the Ilha Grande dam would have closed this stretch, completely putting an end to the phenomenon of floodings and affecting directly all the communities which depend on this factor. It would have also caused the local extinction of various species.

Day duration influences directly water temperature by the penetration of solar rays. It affects the velocity of the metabolic reaction of aquatic organisms. Results obtained in this research work suggest that day duration acts directly on the temporal distribution of larvae. In fact, the greatest densities were verified in the longest day duration. While giving a great deal of importance to this variable, GIAMAS et al. (1988) established a significant relationship between solar radiation 
and the capture of Anchoviela lepidentostole (Fowler, 1911) in the river Ribeira do Iguape in the state of São Paulo, Brazil.

The $\mathrm{pH}$ was not established as a very important variable with regard to the abundance of larvae. Extreme values of this variable were not observed. According to BERGERHOUSE (1992) the environmental $\mathrm{pH}$ should be considered as a factor that limits the survival of valleye larvae [Stizostedion vitreum (Mitchill 1818)]. The same author observed a mortality rate of over $95 \%$ in $\mathrm{pH}$ over 10 with an exposure of more than 300 minutes. LEE \& Hu (1983) established that in laboratory experiments $\mathrm{pH}$ levels from 7.90 to 8.05 do not cause any difference in the survival of eggs of Mugil cephalus (Linnaeus, 1758). While insisting that extremes in the variable are harmful to fish, KORWIN-KOSSAKONSKI (1988) observed in laboratory experiments with Cyprinus carpio (Linnaeus, 1758) that the larvae of this species died within nine days in $\mathrm{pH}$ lower than 5.0.

Electric conductivity which presented high values when the greatest densities of larvae were observed seem to influence the larvae directly. VAZZOLER (1996) states that electric conductivity acts as a synchronizing factor for final maturation, spawning and fertilization in fish. Together with the fluviometric level and food availability it affects specifically the reproductive process.

Reduced density of larvae was registered in December in all the sampling stations, but chiefly in the Patos station where no capture occurred. When the variations of environmental parameters were analysed in this period, it was observed that the fluviometric level was high. The floodplain rich in organic matter was flooded and the concentration of dissolved oxygen was reduced. Emphasizing the importance of this variable for fish larvae, DIONI \& REARTES (1975) registered the death of all Prochilodus platensis (Holemborg, 1889) when tested to hypoxia susceptibility in experimental tanks in which the water had less than $0.6 \mathrm{mgl}^{-1}$ of dissolved oxygen concentration.

In almost all the sampling stations larvae at the surface were predominant. The Paraná station was an exception where the greatest densities were verified at the bottom. This may be associated to food availability at the surface and to the form of the larvae. The predominance of Characiform larvae at the surface and of Siluriforms at the bottom may probably be due to the body form and the habits of these groups.

With regard to the occurrence of larvae at certain times, the preference of the night period by larvae captured at the surface must be established. On the other hand, the greatest captures made at the bottom were undertaken during daytime. In some cases the larvae completely disappeared from a certain layer and did not increase in another. These results show that larvae migrate vertically and horizontally (flight towards the margin) during the nychthemeral cycles. According to NIKOLSKI (1963) daily vertical migrations for feeding are evident in many species of fresh water fish. During daytime they remain at the bottom of the waterbodies to protect themselves from predators. At night they migrate to the surface in search of food. LANSAC-TOHA et al. (1995) studied a lake in the floodplain of the high Paraná River (Lagoa Pousada das Garças) and observed a greater concentration of zooplankton at the surface during the night and at the bottom during the day. This confirms the hypothesis that larvae follow food availability. 
The period of higher density of larvae was longer in more lotic compartments. This suggests that spawning begins at a period before the flooding of the plain and extends itself beyond the period of water ebbing. Such a fact may be observed when results on the fluviometric level are analysed. When the first larvae appear water of the river is still contained in the principal canal; in the flooding phase the larvae are carried to the interior of the lakes; when water recedes captures still occur in the river and in the canals. Studying the Paraná River in its Argentine stretch OLDANI et al. (1992) found that fish larvae were captured in a greater density during January and February, which coincides with the flooding period.

\section{CONCLUSIONS}

The results verified in this research work produced the following conclusions: 1) The Cortado station had the largest density of larvae because of its extensive vegetal covering. 2) The period during which larvae were captured was longer in lotic environments. This is the result of the beginning of spawning when the water is still in the principal channel. 3) The period of greater density of larvae extended from November to March and coincided with the reproduction period of the great majority of the species in the floodplain. 4) Larvae were caught more frequently at the surface during the night period and at the bottom during daytime. This fact shows the vertical and horizontal migration of larvae. 5) The greatest densities were associated to higher temperatures, longer daytime and rising fluviometric level.

ACKNOWLEDGEMENTS. The authors would like to thank the Núcleo de Pesquisas em Limnologia, Ictiologia e Aquicultura (Nupélia) for the help given during the collecting period and to PADCT/CIAMB for the necessary financial suport, to Msc. Cláudia Costa Bonecker and Luiz Carlos Gomes for their help in data analysis.

\section{REFERENCES}

Bergerhouse, D.L. 1992. Lethal effects of elevated pH and ammonia on early life stages of walleye. North Amer. Jour. Fish. Manag. 12: 356-366.

Carvalho J.L. \& B. Merona. 1986. Estudos sobre dois peixes migratórios do baixo Tocantins, antes do fechamento da barragem de Tucurui. Amazoniana 9 (4): 595-607.

Cordiviola DE YuAN, E. 1992. Fish populations of lentic environments of the Paraná River. Hydrobiologia 237: 159-173.

Dioni, W. \& J.L. REARTES. 1975. Susceptibilidad de algunos peces del Paraná medio expuetos a temperaturas extremas en condiciones de campo e laboratorio. Physis 34 (89): 129-137.

Esteves, F. A. 1988. Fundamentos de Limnologia. Rio de Janeiro. Interciência/Finep. 575 p.

Giamas, M.T.D.; L.E. Santos; H. Vermulm JR. \& J.N. SouZA. 1988. Correlação da fluviometria e de alguns fatores climáticos sobre a produção pesqueira de Anchoviella lepidentostole (Fowler, 1911) (Teleostei, Engraulidade), no rio 
Ribeira de Iguape, São Paulo, Brasil. Revta bras. Zool. 4 (4): 251-258. Golterman, H.L.; R.S. Clymo \& M.A.M. OHMSTAD. 1978. Methods for physical and chemical analyses of fresh waters. Oxford, Blackwell Scientific Publication, XVI+214p.

Godoy, M.P. 1954. Locais de desovas de peixes num trecho do rio Mogi-Guaçu, Estado de São Paulo, Brasil. Rev. Brasil. Biol. 4 (4): 375-386. 1975. Peixes do Brasil - Sub ordem Characoidei. Bacia do rio Mogi

Guassu. Piracicaba, Ed. Franciscana, Vol. 4, 848p.

JUNK, W.J. 1980. Áreas inundáveis -um desafio para a limnologia. Acta Amazônica 10 (4): 775-795.

KORWIN-KOSSAKONSKI, M. 1988. Larval development of carp, Cyprimus carpio L., in acidic water. Jour. Fish Biol. 32: 17-26.

LANSAC-TÔHA, F.A.; S.M. THOMAZ; A.F. Lima; M.C. RobERTO \& A.P.P. GARCIA. 1995. Vertical Distribution of Some Planktonic Crustaceans in a "Várzea" Lake (Lake Pousada das Garças) of the Floodplain of High River Parana, MS, Brazil. Int. Jour. Ecol. Env. Sci. 21: 67-78.

LEE, C.S. \& F. HU. 1983. Influences of $\mathrm{Ca}$ and $\mathrm{Mg}$ ions on the egg survival of grey mullet, Mugil cephalus L. Jour. Fish Biol. 22: 15-20.

MANLY, B.F.J. 1995. Multivariate statistical methods - a primer. London, Chapman \& Hall, XII+159p.

Matsuura, Y. 1977. A study of the life History of brasilian sardine, Sardinella brasiliensis. IV. Distribution and abundance of sardine larvae. Bolm. Inst. oceanogr. 26: 219-247.

NAKATANi, K.; J.D. Latini; G. Baumgartner \& M.S.T. Baumgartner. 1993. Distribuição espacial e temporal das larvas de curvina Plagioscion squamosissimus (Heckel, 1840) (Osteichthyes, Scianidae), no reservatório de Itaipu. Unimar 15: 191-203.

NikOLSKI, G.V. 1963. The ecology of fishes. London, Academic Press, XV+352p. Oldani, N.O.; J.M. IWASZKim; O.H. PANDin \& A. OTAEGUi. 1992. Flutuaciones de la abundancia de peces en el Alto Paraná (Corrientes, Argentina). Publ. Comis. Rio Uruguay 1: 43-55.

SNYDER, D.E. 1983. Fish eggs and larvae, p. 165-197. In: L.A. NielSEN \& D.L. JOHNSON (Eds). Fisheries technique. Bethesda, American Fisheries Society, Vol. 9.

TANAKA, S. 1973. Stock assesment by means of ichtyoplankton surveys. FAO Fish Tech. Pap. 122: 33-51.

Thomaz, S.M.; M.C. Roberto; F.A. Esteves; F.A. LANSAC-TôHa \& A.F. Lima. 1992. Influência do regime hidrológico do rio Paraná sobre os valores da transparência, oxigênio dissolvido e clorofila-a de três lagoas de sua várzea. Unimar 14 (Supl.): 153-162.

VAZZOLER, A.E.A.M. 1996. Biologia da reprodução de peixes teleósteos: teoria e prática. Maringá, EDUEM, XVII+169p. 